\title{
AN OPTIMIZATION PROBLEM IN A FINITE MARKOV CHAIN APPLIED TO SOLID PARTICLE MIXING
}

\author{
Keisuke Uchimura Tadashi Yoshizawa \\ Yamanashi University Yamanashi University \\ Kenichi Shimura \\ Yamanashi University
}

(Received January 20, 1981; Final February 25, 1983)

Abstract Consider a Markov chain with $n$ states and a symmetric tridiagonal transition probability matrix $P$. Let $C$ be a class of vectors $\{p(0)\}$ such that half the elements of $p(0)$ are zero and another half are 1 . The problem is to find the vector $p(0)$ in $C$ such that the value ||$p(0) P^{N}-p(\infty)|\cdot|$ is the minimum for any large nonnegative integer $N$, where $p(\infty)=(1 / 2,1 / 2, \ldots, 1 / 2)$ and $p(\infty)$ is called a stationary concentration vector. The solution is stated as follows. The optimal vectors in a sense defined in this paper are of the form $\left(p_{0}, p_{1}, \ldots, p_{n-1}\right)$ which satisfy the following conditions: $p_{k}=p_{3-k}, p_{k}=p_{4 g+k}$ for $0 \leqq k \leqq 3$ and $0 \leqq g \leqq 2^{m-2}-1$, where $n=2^{m}$ $(m \geqq 2)$. The optimal vectors can be represented as repetition of 0110 or 1001 .

This problem was related to models for mixing process of particulate solids. The optimal solutions have been conjectured through the computer simulation conducted by Akao et al. The objective of this paper is to support the mathematical background for their experimental results and to show an interesting property of Markov chains.

\section{Introduction}

The problem formulated and solved in this paper is to find an optimal initial distribution for Markov chains with some specific transition probability matrix. An initial distribution is said to be optimal if the speed of convergence from the initial distribution to the stationary one is the maximal.

This problem was first suggested by Akao, who has proposed a significant approach to analyse mixing processes of solid particles.

Mixing process in a conventional solids mixer is governed mainly by two basic mechanisms, convection and diffusion. In fact, fairly regular deterministic bulk flow of particles and very irregular stochastic movement of individual particles will be easily observed typically if the two kinds of 
particles are mixed by a horizontal rotating drum mixer, which is probably one of the simplest types of conventional solids mixer used in various industries. However, real motions are extremely complicated and depend on the shape, density and other physical characteristic of particles as well as types of mixers. Mixing is one of the difficult problems to analyse in chemical engineering.

Akao et a1. [1,4] regard mixing process as a synthesized one with two independent operational units which correspond to convention and diffusion. They have proposed a probabilistic branching model for diffusive unit, and studied for convection unit optimal constitution of strata fed to the following diffusive unit. The problems of constitution of strata may be observed, for examples, at strata of cokes and ores in blast furnace in iron-works. If we find the optimal constitution of strata, we can considerably shorten the time required for the mixing.

Numerical and experimental simulation studies on mixing of particulate solids have been reported in Akao et al. [1, 3, 4]. The details of further results and of their applicability to the design of practical mixers will be published in Akao et al. [2]. Concerning the problem solved here, the optimal solutions has been conjectured through their extensive computer simulation $[2,3]$.

The objective of the present paper is to support the mathematical background for their experimental results. We can regard the constitution of strata as initial distributions for Markov chains. Hence if we can find the optimal initial distribution, we can get the optimal constitution of strata accordingly .

In the second section the probability branching model mixer and the structure of the transition probability matrix will be described on the basis of a Markov chain. The optimization problem to be solved here will be formulated in the third section, where eigenvalues and eigenvectors of the transition probability matrix will be also derived, showing a numerical example. In the fourth section, an algebraic proof of the theorem concerning the optimality will be given. In the fifth section, several modifications of the Markov chain model will be discussed. The approach to this problem will be interesting for readers of this journal since applications of Markov chains are broad in the field of Operation Research.

\section{A Probabilistic Branching Model and Feeding Vectors}

Akao has proposed an ideally synthesized model both of convective and 
diffusive mixing processes as shown in Fig. 1, which is a revised version of Fig. 7 in [4]. The upper parts and the central parts of the mixer represent stratified feeders which play a role of convection and a probabilistic branching model mixer which realizes diffusion, respectively. The lower parts are simply receivers of the mixture.

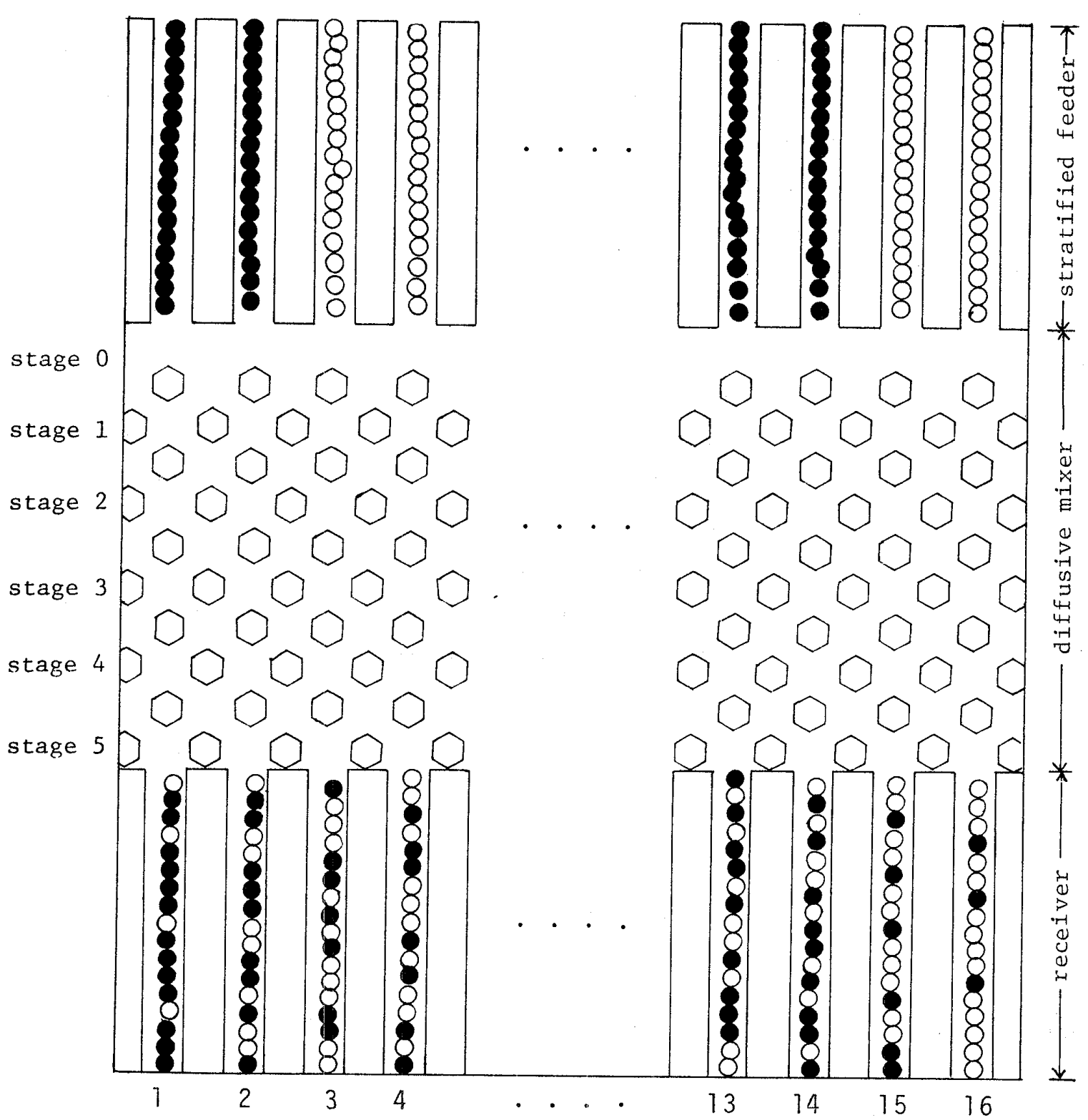

Fig. 1 A stratified feeding mixer and a probabilistic branching model mixer. 
This paper deals with the mixture of only two kinds of homogeneous solid particles, whose total concentration is fixed to be one to one. Two kinds of particles are classified into 0 (white) and 1 (black) here for convenience. Each feeder supplies particles either of type 0 or 1, so that the combination of feeders is represented by a vector with the elements of 0 and 1. The vectors are named "feeding vectors". In Fig. 1, the feeding vector is expressed as a row vector $(1,1,0,0,1,1,0,0,1,1,0,0,1,1,0,0)$.

The probabilistic branching model mixer depicted in Fig. 1 is an inclined board with rows of hexagonal blocks set apart by a small distance. Particles with a diameter of slightly less than the distance between the blocks are dropped from the feeders. They are allowed to run down between the hexagonal blocks and are collected in the receivers at the bottom of the board. On their way down, particles are assumed to be independent of each other, that is, no interference exists. The rows numbered by every other rows in Fig. 1 are called stages, at which the locations between hexagonal blocks are called cells. The number of cells is denoted by $n$. In Fig. 1, each stage has 16 cells.

Motions of particles in the probabilistic branching mode1 in [4] was considered a Markov chain as follows: the cells at each stage constitute a state space; the transition probability $P_{i j}$ from the state $i$ to the state $j$ is the probability that a particle which is located on the $i$-th cell at any stage moves to the $j$-th cell at the next stage; the transition probability matrix with the elements $P_{i j}$ 's is of the form

$$
P=\left[\begin{array}{ccccc}
3 / 4 & 1 / 4 & & \\
1 / 4 & 1 / 2 & 1 / 4 & 0 \\
& \ddots & \ddots & \ddots & \\
& \cdot & \ddots & \ddots & \cdot \\
0 & 1 / 4 & 1 / 2 & 1 / 4 \\
0 & & & 1 / 4 & 3 / 4
\end{array}\right],
$$

where $P$ is a real symmetric tridiagonal matrix. The quantities of $P_{i j}$ 's can be evaluated under the assumptions that a particle at any row branches with equal probability of $1 / 2$ except at the walls, and both side walls are reflective.

Let us denote a row vector of an initial distribution by $\Pi(0)$ in the case that only one particle is dropped. The element $\Pi_{i}(0)$ of $\Pi(0)$ means the probability that the particle is supplied from the $i$-th feeder $(i=1,2$, $\ldots, n)$. It is known that the distribution $\Pi(N)$ at the stage $N$ is given by 
(2.2) $\quad \Pi(N)=\Pi(0) P^{N}$

and that the stationary distribution $\Pi(\infty)$ exists and is equal to $(1 / n, 1 / n$, $1 / n)$. Note that the element $\Pi_{i}(N)$ of $\Pi(N)$ represents the probability that the dropping particle passes the $i$-th cell at stage $N$.

Suppose that many particles are supplied continuously and that the number of one kind of particles, e.g. black ones, follows the initial distribution $\Pi(0)$. The quantity $(n / 2) \Pi(N)$ can be interpreted as the expected concentration vector whose element represents the concentration ratio of black particles at each cell after $N$ stages.

A feeding vector with $0-1$ elements is denoted by $p(0)$. Since $p(0)$ is nothing but an initial concentration vector, $p(N)$ which is defined by

$$
p(N)=p(0) P^{N},
$$

is equivalent to the expected concentration vector mentioned above, i.e.

$$
\text { (2.4) } \quad p(N)=(n / 2) \Pi(N) .
$$

Then, we obtain

$$
\begin{aligned}
p(\infty) & =(n / 2) \Pi(\infty) \\
& =(1 / 2,1 / 2, \ldots, 1 / 2)
\end{aligned}
$$

as a stationary concentration vector, when the number of stages $N$ approaches to infinity. The mixture with this stationary concentration vector is called "complete".

Akao et a1. [2] have shown that the speed of convergence of $P(N)$ to $p(\infty)$ greatly depends on the feeding vectors. Moreover, they have conjectured the feeding vectors which are optimal in a sense. For example, the feeding vector $(1,0,0,1,1,0,0,1,1,0,0,1,1,0,0,1)$ is conjectured to be optimal for the case $n=16$ in Fig. 1. Note that the distinction of 0 and 1 in feeding vectors is not essential, since the same discussion as above is possible for the concentration of white particles instead of black ones.

\section{Statement of the Problem and an example}

Consider a finite Markov chain with $n$ states and with the transition probability matrix $P$ of the form 
(3.1)

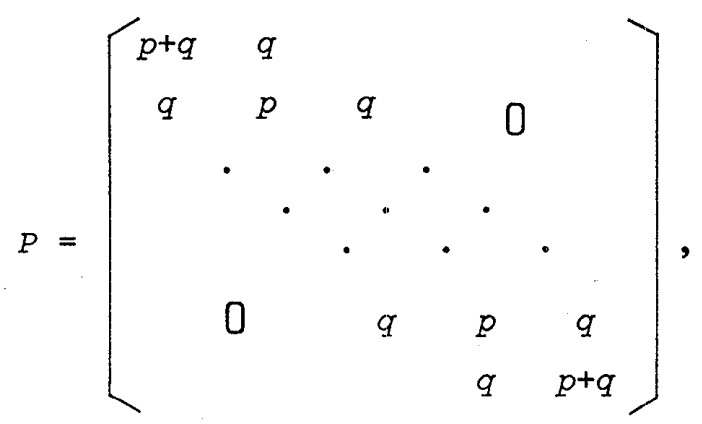

where $P$ is a real symmetric tridiagonal matrix of size $n \times n$, and

$$
1>p \geqq 1 / 2
$$

and

$$
p+2 q=1
$$

The case in which $p$ is $1 / 2$ is reduced to the model with the transition probability matrix (2.1) described in the previous section, while the other cases in which $p$ is greater than $1 / 2$ may be physically interpreted as models in which some interferences among particles occur. If the condition (3.2) is satisfied, $P$ is positive definite and has the distinct eigenvalues as will be shown in Appendix A. The condition (3.3) shows that the sum of the elements of each row in $P$ is equal to 1 .

The problem to be solved here is to find a feeding vector $p(0)$ such that the expected concentration vector $p(N)$ defined by (2.3) converges to the stationary concentration vector $p(\infty)$ as fast as possible. The speed of convergence may be measured with the smallest value of $N$ that satisfied the condition;

$$
\|p(N)-p(\infty)\|_{E}<\varepsilon
$$

for a sufficiently small $\varepsilon$, where \|\|$_{E}$ denotes Euclidean norm about vectors. Now, we denote the eigenvalues and the corresponding eigenvectors of the transition probability matrix $P$ by $\lambda_{j}$ and $\bar{u}_{j}(j=0,1, \ldots, n-1)$ respectively, i.e.

$$
\dot{P}_{j}=\lambda_{j} \bar{u}_{j}, \quad j=0,1, \ldots, n-1,
$$

where $\lambda_{j}$ 's are arranged as

$$
\lambda_{0}>\lambda_{1}>\ldots>\lambda_{n-1}>0
$$

and $\bar{u}_{j}$ 's are assumed to be normalized as

$$
\text { (3.7) } \quad t \bar{u}_{j} \vec{u}_{j}=1, \quad j=0,1, \ldots, n-1 \text {, }
$$


so that they are orthonormal. Note that $\bar{u}_{i}$ is a column vector, while $p(N)$ is a row vector, and that $t$ means transposition of a vector or a matrix, hereafter.

It is well known that the maximum eigenvalue of the probability matrix $P$ is 1 , and that $P$ is decomposable to the form

$$
P=\sum_{j=0}^{n-1} \lambda_{j} \bar{u}_{j} t_{\bar{u}_{j}}
$$

From the above facts and the orthonormality of the $\bar{u}_{j}$ 's, we can easily obtain.

$$
\begin{aligned}
P^{N} & =\sum_{j=0}^{n-1} \lambda_{j}^{N-\bar{u}_{j}}{ }_{j}^{t} \bar{u}_{j} \\
& =\bar{u}_{0} \bar{u}_{0}+\sum_{j=1}^{n-1} \lambda_{j}^{N} \bar{u}_{j} t_{\bar{u}_{j}} .
\end{aligned}
$$

Therefore, the expected concentration vector $p(N)$ of (2.3) is expressed as

$(3.10)$

$$
p(N)=p(0) P^{N}=\sum_{j=0}^{n-1} \lambda_{j}^{N}\left(p(0) \bar{u}_{j}\right) \bar{u}_{j}
$$

$$
=a_{0} \bar{u}_{0}+\sum_{j=1}^{n-1} \lambda_{j}^{N}{ }_{j}^{t} \bar{u}_{j},
$$

where $a_{j}$ is the inner product of $p(0)$ and $\bar{u}_{j}$, i.e.,

$$
\text { (3.11) } \quad a_{j}=p(0) \bar{u}_{j}, \quad 0 \leqq j \leqq n-1 \text {. }
$$

Since the maximal eigenvalue $\lambda_{0}$ is 1 and the other $\lambda_{j}$ 's are less than 1 , we obtain

(3.12) $\quad p(\infty)=a_{0} \bar{u}_{0}$

From (3.10) and (3.12), inequality (3.4) can be written as

$$
\|p(N)-p(\infty)\|_{E}=\left\|\sum_{j=1}^{n-1} \lambda_{j}^{N}{ }_{j}^{t} \bar{u}_{j}\right\|_{E}=\left(\sum_{j=1}^{n-1} \lambda_{j}^{2 N} a_{j}^{2}\right)^{1 / 2}<\varepsilon .
$$

Then, let us define the quantity $\sigma(N)$ as

$$
\sigma(N)=\left\|\sum_{j=1}^{n-1} \lambda_{j}^{N} a_{j}^{t-}\right\|_{j} \|_{E} / n^{1 / 2}
$$

It is easily observed that $\sigma(N)$ will be dominated by $\lambda_{1}^{2 N} a_{1}^{2}$ for a sufficiently large $N$ if $a_{1}$ is not equal to zero. $\lambda_{k}^{2 N} a_{k}^{2}$ is said to be the principal term 
of $\sigma(N)$ if $a_{k}$ is the first nonzero factor in (3.14), that is

$$
a_{1}=a_{2}=\ldots=a_{k-1}=0 \text {, and } a_{k} \neq 0
$$

Consider a class $C$ of feeding vectors $\{p(0)\}$ such that half the elements of $p(0)$ are zero and another half are 1 . We order the vectors in $C$ as follows. For any $p_{1}$ and $p_{2}$ in $C$, let

(3.15) $\quad p_{1} \bar{u}_{1}=\ldots=p_{1} \bar{u}_{k-1}=0, p_{1} \bar{u}_{k} \neq 0$ and

(3.16) $p_{2} \bar{u}_{1}=\ldots=p_{2} \bar{u}_{s-1}=0, p_{2} \bar{u}_{s} \neq 0$. Then,

(3.17) $p_{1} \leqq p_{2}$ if and only if $k>s$ or both $k=s$ and $\left|p_{1} \bar{u}_{k}\right| \leqq\left|p_{2} \bar{u}_{k}\right|$ hold.

The minimal elements are called the optimal feeding vectors. It is clear that if $p(0)$ is an optimal feeding vector, the smallest integer $N$ satisfying the condition (3.4) with $p(0)$ is the smallest of all integers with vectors in $C$.

Problem Find the optimal feeding vectors in $C$.

Note that the feeding vector $p(0)$ is regard to be proportioned to an initial distribution $\Pi(0)$ as mentioned in the previous section, so that this problem can be stated concerning initial distribution instead of feeding vectors.

Now, let us show the eigenvalues and eigenvectors of the transition probability matrix $P$ of (3.1). The datails of their derivation will be described in Appendix A. The eigenvalues of $P$ are given by

$$
\lambda_{j}=p+y_{j} q, \quad 0 \leqq j \leqq n-1
$$

where

$$
y_{j}=2 \cos (j \pi / n), \quad 0 \leqq j \leqq n-1 .
$$

The corresponding eigenvectors $u_{j}$, whose elements are denoted by $u_{j, k}$ $(0 \leqq k \leqq n-1)$, are expressed as

$$
u_{j, k}=\cos ((2 k+1) j \pi / 2 n), \quad j=0,1, \ldots, n-1
$$

Note that

(3.21) $\quad \bar{u}_{0}=u_{0} / n^{1 / 2}, \quad \bar{u}_{j}=u_{j} /(n / 2)^{1 / 2}, \quad j \geqq 1$.

It is worthy of notice that the eigenvectors do not depend on $p$ and $q$. Since $y_{j}$ 's are distinct and 


$$
\left|y_{j}\right| \leqq 2, \quad j=0,1, \ldots, n-1,
$$

the eigenvalues of $P$ are distinct and positive if $p$ and $q$ satisfy (3.2) and (3.3). Note that $\lambda_{0}$ is equal to 1 as well known, and that

$$
u_{0}={ }^{t}(1,1, \ldots, 1) \text {. }
$$

Thus, we know from (3.11),

$$
a_{0}=n^{1 / 2} / 2
$$

and

$$
p(\infty)=a_{0}{ }^{t} u_{0} /\left({ }^{t} u_{0} u_{0}\right)^{1 / 2}=(1 / 2, \ldots, 1 / 2),
$$

for any $p(0)$ which belongs to the class restricted in the problem.

The number of entries of the class $\{p(0)\}$ is finite for any fixed $n$, so that the optimal feeding vectors can be determined if a11 entries are surveyed. Let us show an example below. Remark that the eigenvectors in

\begin{tabular}{|c|c|c|c|c|c|c|c|c|c|c|c|c|c|c|c|c|}
\hline \multirow{2}{*}{$\begin{array}{l}\text { ele- } \\
\text { ments }\end{array}$} & \multicolumn{16}{|c|}{ eigen vectors } \\
\hline & 0 & 1 & 2 & 3 & 4 & 5 & 6 & 7 & 8 & 9 & 10 & 11 & 12 & 13 & 14 & 15 \\
\hline 0 & 1. & 1. & .98 & .96 & .92 & .88 & .83 & .77 & .71 & .63 & .56 & .47 & .38 & .29 & .20 & .10 \\
\hline 1 & 1. & .96 & .83 & .63 & .38 & .10 & -.20 & -.47 & -.71 & -.88 & -.98 & -1 & -.92 & -.77 & -.56 & -.29 \\
\hline 2 & 1. & .88 & .56 & .10 & -.38 &.- .77 & -.98 & -.96 & -.71 & -.29 & .20 & .63 & .92 & 1 & .83 & .47 \\
\hline 3 & 1. & .77 & .20 & -.47 & -.92 & -.96 & -.56 & .10 & .71 & 1. & .83 & .29 & -.38 & -.88 & -.98 & -.63 \\
\hline 4 & 1. & .63 & -.20 & -.88 & -.92 & -.29 & .56 & 1. & .71 & -.10 & -.83 & -.96 & -.38 & .47 & .98 & .77 \\
\hline 5 & 1. & .47 & -.56 & -1 & -.38 & .63 & .98 & .29 & -.71 & -.96 & -.20 & .77 & .92 & .10 & -.83 & -.88 \\
\hline 6 & 1. & .29 & -.83 & -.77 & .38 & 1. & .20 & -.88 & -.71 & .47 & .98 & .10 & -.92 & -.63 & .56 & .96 \\
\hline 7 & 1. & .10 & -.98 & -.29 & .92 & .47 & -.83 & -.63 & .71 & .77 & -.56 & -.88 & .38 & .96 & -.20 & -1 \\
\hline 8 & 1. & -.10 & -.98 & .29 & .92 & -.47 & -.83 & .63 & .71 & -.77 & -.56 & .88 & .38 & -.96 & -.20 & 1. \\
\hline 9 & 1. & -.29 & -.83 & .77 & .38 & -1 & .20 & .88 & -.71 & -.47 & .98 & -.10 & -.92 & .63 & .56 & -.96 \\
\hline 10 & 1. & -.47 & -.56 & 1. & -.38 & -.63 & .98 & -.29 & -.71 & .96 & -.20 & -.77 & .92 & -.10 & -.83 & .88 \\
\hline 11 & 1. & -.63 & -.20 & .88 & -.92 & .29 & .56 & -1 & .71 & .10 & -.83 & .96 & -.38 & -.47 & .98 & -.77 \\
\hline 12 & 1. & -.77 & .20 & .47 & -.92 & .96 & -.56 & -.10 & .71 & -1 & .83 & -.29 & -.38 & .88 & --.98 & .63 \\
\hline 13 & 1. & -.88 & .56 & -.10 & -.38 & .77 & -.98 & .96 & -.71 & .29 & .20 & -.63 & .92 & -1 & .83 & -.47 \\
\hline 14 & 1. & -.96 & .83 & -.63 & .38 & -.10 & -.20 & .47 & -.71 & .88 & -.98 & 1. & -.92 & .77 & -.56 & .29 \\
\hline 15 & 1. & -1 & .98 & -.96 & .92 & -.88 & .83 & -.77 & .71 & -.63 & .56 & -.47 & .38 & -.29 & .20 & -.10 \\
\hline $\begin{array}{l}\text { gen } \\
\text { lives }\end{array}$ & 1. & .99 & .96 & .92 & .85 & .78 & .69 & .60 & .50 & .40 & .31 & .22 & .15 & .08 & .04 & 01 \\
\hline
\end{tabular}
Table 1 are not normal.

Example 1. $\quad n=16$

Table 1. Eigen values and vectors of the stochastic matrix $P_{16}$ 
We have computed the integer $k$ such that $a_{k}$ is the first nonzero factor in (3.14) and the value $a_{k}$ for fifteen feeding vectors of size 16. Further we have evaluated the minimal integer $N_{0}$ that satisfies the inequality

$$
\sigma^{2}\left(N_{0}\right) \leqq 1 / 4000 \text {, }
$$

for each feeding vector by direct computation.

Besides we have determined another integer $M$ for each feeding vector as follows. Let $\lambda_{k}^{2 N} a_{k}^{2}$ be the principal term of $\sigma(N)$ for the vector. We have determined the minimal integer $M$ that satisfies the inequality

$$
\lambda_{k}^{2 M} a_{k}^{2} / 16 \leqq 1 / 4000 \text {. }
$$

The result is depicted in the following table.

Table 2. Speed of Convergence

\begin{tabular}{ccccrr} 
& patterns & $k$ & $a_{k}$ & $N_{0}$ & \multicolumn{1}{c}{$M$} \\
A & 1111111100000000 & 1 & 1.80 & 348 & 348 \\
B & 1001100110011001 & 8 & 2.00 & 5 & 5 \\
C & 1111000011110000 & 1 & 0.75 & 256 & 256 \\
D & 1111000000001111 & 2 & 1.81 & 87 & 87 \\
E & 1100110011001100 & 1 & 0.36 & 180 & 180 \\
F & 1100110000110011 & 2 & 0.75 & 64 & 64 \\
G & 1100001111000011 & 4 & 1.85 & 22 & 22 \\
H & 1010101010101010 & 1 & 0.18 & 107 & 107 \\
I & 1010101001010101 & 2 & 0.36 & 45 & 45 \\
J & 1010100110010101 & 2 & 0.25 & 36 & 36 \\
K & 1010011001100101 & 2 & 0.11 & 17 & 14 \\
L & 1001010110101001 & 2 & -0.25 & 36 & 36 \\
M & 1001011001101001 & 2 & -0.15 & 23 & 23 \\
N & 1001101001011001 & 2 & 0.11 & 17 & 14 \\
O & 1010010110100101 & 4 & 0.77 & 16 & 16
\end{tabular}

In this table we can see that $\sigma^{2}(N)$ is dominated by the principal term $\lambda_{k}^{2 N} a_{k}^{2}$ for any large $N$.

Here we explain the reason for using the value $1 / 4000$ in (3.22) and (3.23).

Akao et a1. compared the speed of convergence among the fifteen feeding vectors by computer simulation. Although $\sigma(N)$ becomes zero in the complete mixed state, the simulation results are acompanied by the error of the simple random sampling. The value $\sigma_{r}^{2}$ of the error is evaluated to be

$$
\sigma_{r}^{2}=p(1-p) / k
$$

based on the binomial distribution, where $k$ is the number of particles fed at each cel1 (See, [2]). The criterion of convergence can be determined as

$$
\sigma^{2}(N) \leqq \sigma_{x}^{2} / 10
$$


from the convention which is practically employed in the field of sampling. In their simulation 100 particles were fed.

In order to compare our result with theirs, we chose the value $1 / 4000$ and evaluated the integers $N_{0}$ and $M$.

In Table 2 we see the fact that the speed of convergence of the pattern $B$ is the fastest, which accords with the result of the computer simulation stated in [2].

4. Optimal Solutions in the case that $n=2^{m}$

In this section, the theorem which gives the optimal solutions of the problem will be proved, where $n=2^{m}$.

Theorem. Where $n=2^{m}$ ( $m \geqq 2$ ), the optimal feeding vectors of the problem stated in the previous section are the feeding vectors of the form $\left(p_{0}, p_{1}, \ldots, p_{n-1}\right)$ which satisfy the following condition $c_{m-2}$;

$$
\begin{aligned}
C_{m-2}: & p_{k}=p_{4-1-k}, \\
p_{k} & =p_{4 \times q+k}, \\
0 \leqq k & \leqq 3, \quad 0 \leqq g \leqq 2^{m-2}-1 .
\end{aligned}
$$

Representing the optimal vector $\left(p_{0}, p_{1}, \ldots, p_{n-1}\right)$ as a string $p_{0} p_{1} \ldots$ $p_{n-1}$, we have

$$
p_{0} p_{1} \cdots p_{n-1}=\alpha_{m-2},
$$

where $\alpha_{i}=\alpha_{i-1} \alpha_{i-1}$, and $\alpha_{0}=0110$ (or 1001) (the symbol $*$ denotes a concatenation product of two strings).

To prove the theorem we need some preparation. Recall that from (3.20) we have

$$
u_{j, k}=\cos ((2 k+1) j \pi / 2 n), \quad 0 \leqq j, k \leqq n-1 .
$$

Let $\zeta=\exp (2 \pi i / 4 n)$. Clearly $\zeta$ is a primitive $4 n$-th root of unity. Then we have

$$
2 u_{j, k}=\zeta^{j(2 k+1)}+\zeta^{-j(2 k+1)}, \quad 0 \leqq k \leqq n-1,
$$

since $\zeta=\cos (2 \pi / 4 n)+i \sin (2 \pi / 4 n)$. Note that

$$
\zeta^{2^{m+2}}=1 \text { and } \zeta^{2^{m+1}}=-1
$$

First we show a condition for $p(0)$ to make the equality $p(0) u_{1}=0$ valid. 
Note that $2 u_{1}={ }^{t}\left(\zeta+\zeta^{-1}, \zeta^{3}+\zeta^{-3}, \ldots, \zeta^{2 n-1}+\zeta^{-(2 n-1)}\right)$ and each element of $p(0)$ is 1 or 0 .

Lemma 1. The equality,

$$
\left.2_{k=0}^{m} \sum_{k}^{-1} c^{2 k+1}+\zeta^{-(2 k+1)}\right)=0
$$

where each $c_{k}$ is in the rational number field $Q$, is valid if and only if

$$
c_{k}=c_{2^{m}-1-k} \text { for all } k=0,1, \ldots, 2^{m}-1 .
$$

Proof: Let $\phi_{2^{m+2}}(x)$ be the $2^{m+2}-$ th cyclotomic polynomial. It is known that

$$
{ }_{2}{ }^{m+2}(x)=\prod_{d \mid 2^{m+2}}\left(x^{d}-1\right)^{\mu\left(2^{m+2} / d\right)}
$$

where $\mu$ is the Moebius function (See Van der Waerden [6]). Hence

$$
\phi_{2}{ }^{m+2}(x)=x^{2^{m+1}}+1
$$

It is known that any cyclotomic polynomial is irreducible over $Q$. Therefore $x^{2^{m+1}}+1$ is irreducible over $Q$. This tells us that the polynomial $x^{2^{m+1}}+1$ is the minimal polynomial over $Q$ for $\zeta$. Multiply the eq. $(4.1)$ by $\zeta^{2^{m+1}-1}$ We get

$$
\sum_{k=0}^{2^{m}-1} c_{k}\left(\zeta^{2 k+2^{m+1}}+\zeta^{2^{m+1}-2 k-2}\right)=0
$$

Since $\zeta^{2^{m+1}}=-1$, we have

$$
\left(-c_{0}+{ }_{2} 2_{-1}\right)+\zeta^{2}\left(-c_{1}+c_{2^{m}-2}\right)+\ldots+\zeta^{2^{m+1}-4}\left(-c_{2^{m}-2}+c_{1}\right)+\zeta^{2^{m+1}-2}\left(-c_{2^{m}-1}+c_{0}\right)=0 .
$$

Therefore we have

$$
c_{k}=c_{2^{m}-1-k}, \quad\left(0 \leqq k \leqq 2^{m}-1\right),
$$

since $x^{2^{m+1}}+1$ is the minimal polynomial for $\zeta$.

Q. E. D.

Next we show the condition of $p(0)$ for $p(0) u_{j}=0$ when $j$ is an odd integer.

Recall that 


$$
2 u_{j}={ }^{t}\left(\zeta^{j}+\zeta^{-j}, \zeta^{3 j}+\zeta^{-3 j}, \ldots, \zeta^{j(2 n-1)}+\zeta^{-j(2 n-1)}\right) .
$$

Corollary 1. Let $j$ be an odd integer. Then

$$
\sum_{k=0}^{2^{m}-1} c_{k}\left(\zeta^{j(2 k+1)}+\zeta^{-j(2 k+1)}\right)=0
$$

if and only if $c_{k}=c_{2^{m}-1-k}$ for a11 $k, \quad\left(0 \leqq k \leqq 2^{m}-1\right)$

The proof follows from the fact that $\zeta^{j}$ is a primitive $4 n$-th root of unity for any odd integer $j$.

We classify the set of eigenvectors $\left\{u_{j} \mid j=1,2, \ldots, 2^{m}-1\right\}$ as follows. Let $V_{r}=\left\{u_{j} \mid j\right.$ is divisible by $2^{r}$ but not divisible by $\left.2^{r+1}\right\}$. Note that $0 \leqq r \leqq m-1$.

Lemma 2. The following property is valid for any eigenvector $u_{j} \varepsilon V_{r}$ whenever $1 \leqq r$.

$$
\begin{array}{ll}
u_{j, k}=u_{j, 2^{m-r+1}-1-k}, & \left(0 \leqq k \leqq 2^{m-r+1}-1\right), \\
u_{j, k}=u_{j, 2^{m-r+1}}{ }_{x g^{+k}}, & \left(0 \leqq g \leqq 2^{r-1}-1\right) .
\end{array}
$$

Proof: First we show the lemma holds for ${ }_{2} r^{\cdot}$ Clearly,

$$
\begin{aligned}
2 u{ }_{2}, k & =\zeta^{2^{r}(2 k+1)}+\zeta^{-2^{r}(2 k+1)} \\
& =\zeta^{-2^{r}\left(2^{m-r+2}-2 k-1\right)}+\zeta^{2^{r}\left(2^{m-r+2}-2 k-1\right)} \\
& =2 u{ }^{r}, 2^{m-r+1}-1-k
\end{aligned}
$$

since $\zeta^{2^{m+2}}=1$

Also for any $g$ we have

$$
\begin{aligned}
2 u{ }_{2}{ }^{r}, k & =\zeta^{2^{r}(2 k+1)}+\zeta^{-2^{r}(2 k+1)} \\
& =\zeta^{2^{r}\left(2^{m-r+2} \times g+2 k+1\right)}+\zeta^{-2^{r}\left(2^{m-r+2} \times g+2 k+1\right)} \\
& =u_{2^{r}, 2^{m-r+1} \times g+k} .
\end{aligned}
$$


By the similar method, we can prove that the lemma is valid for any $u_{j} \varepsilon V_{r}$, since we use only the property; $\zeta^{2^{m+2}}=1$ to prove the lema for $u_{2}$. Q.E.D.

This situation can be seen clearly in Table 1.

We shall find a necessary and sufficient condition for $p(0)$ to make the equality $p(0) u=0$ valid for every $u$ in $v_{0} \cup v_{1} \cup \ldots U v_{r}$. Let

$$
p(0)=\left(p_{0}, p_{1}, \ldots, p_{2_{-1}}\right) \text {. }
$$

We denote by $C_{r}$ the following condition;

and

$$
p_{k}=p_{2^{m-1-k}} \quad\left(0 \leqq k \leqq 2^{m-r}-1\right)
$$

$$
p_{k}=p_{2^{m-r+k}}, \quad\left(0 \leqq g \leqq 2^{r}-1\right) \text {. }
$$

Lemma 3. The equality $p(0) u=0$ is valid for every $u$ in $v_{0} \cup V_{1} \cup \ldots$ .. $U V_{r}$, if and only if $p(0)$ satisfies the condition $C_{r}$.

Proof: By induction. If $r=0$, we can prove the assertion by Lemma 1 and Collorary 1.

Assume the lemma proved for $r-1$. Then

$$
p_{k}=p_{2}^{m-r+1}-1-k
$$

$$
\begin{aligned}
& p_{k}=p_{2}{ }^{m-r+1} \times g+k \\
& \left(0 \leqq k \leqq 2^{m-r+1}-1\right), \quad\left(0 \leqq g \leqq 2^{r-1}-1\right) .
\end{aligned}
$$

From Lemma 2, for any $u_{j} \varepsilon V_{r}$, we find

$$
u_{j, k}=u_{j, 2^{m-r+1}-1-k}
$$

$$
u_{j, k}=u_{j, 2^{m-r+1} \times g+k},
$$

where $j=2^{r} \times q$ and $q$ is an odd integer. We may assume without loss of generality that $q=1$. Assume that $p(0) u_{2} r=0$. Then we have

$$
\sum_{k=0}^{2^{m-r}-1} p_{k}\left(\zeta^{2^{r}(2 k+1)}+\zeta^{-2^{r}(2 k+1)}\right)=0
$$

It is obvious that $\zeta^{2^{r}}$ is a primitive $2^{m-r+2}-t h$ root of unity. Hence from Lemma 1 and $(4.2)$ we have 


$$
\begin{aligned}
& p_{k}=p_{2^{m-r}-1-k}{ }^{m} \\
& p_{k}=p_{2^{m-r} \times g+k}, \\
& \left(0 \leqq k \leqq 2^{m-r}-1\right), \quad\left(0 \leqq g \leqq 2^{r}-1\right) .
\end{aligned}
$$

This is the condition $C_{r}$ 。

Q. E. D.

Proof of Theorem: As stated in Lemma 3, the following properties are equivalent to each other:

(1) $p(0) u_{i}=0$ for a11 $u_{i}\left(1 \leqq i \leqq 2^{r}-1\right)$.

(2) $p(0) u_{i_{j}}=0$ for every, $u_{i_{j}}(1 \leqq j \leqq x)$, where $u_{i_{j}}$ is any element of

$$
v_{j-1}(1 \leqq j \leqq m) \text { and } 1 \leqq x \leqq m .
$$

If $p(0) u_{i j}=0$ for every $u_{i}(1 \leqq j \leqq m), p(0)=(0,0, \ldots, 0)$ or $(1,1, \ldots, 1)$. Since half the elements of $p(0)$ are zero and another half are 1 , we have the optimum feeding vector $p(0)$ if $p(0) u_{i_{j}}=0(1 \leqq j \leqq m-1)$ and $p(0) u_{i_{m}} \neq 0$. Hence it follows from Lemma 3 that the optimum feeding vector $p(0)$ is equal to $p_{1}=(0,1,1,0,0,1,1,0, \ldots, 0,1,1,0)$ or $p_{2}=(1,0,0,1,1,0,0,1, \ldots, 1,0,0,1)$.

Q. E. D.

\section{Discussion}

In this section we consider several modification of the previous Markov chain mode1.

(a) Classes of feeding vectors

In Problem we assume that half the elements of $p(0)$ are zero and another half are 1. However we can apply our theory to the case where the total concentration ratio is not equal to $1 / 2$.

For instance we consider the following case: $n=16$ and the total concentration ratio is equal to $1 / 4$. By similar analysis we can show that the optimal feeding vectors are included in the following vectors.

$$
\begin{aligned}
& F 1:(1,0,0,0,0,0,0,1,1,0,0,0,0,0,0,1), \\
& F 2:(0,1,0,0,0,0,1,0,0,1,0,0,0,0,1,0), \\
& F 3:(0,0,1,0,0,1,0,0,0,0,1,0,0,1,0,0), \\
& F 4:(0,0,0,1,1,0,0,0,0,0,0,1,1,0,0,0) .
\end{aligned}
$$


Clearly $a_{i}(1 \leqq i \leqq 3)$ is zero for any $F j(1 \leqq j \leqq 4)$. But $a_{4}$ is not zero for any of these feeding vectors.

$$
\begin{aligned}
& a_{4}=1.30 \text { for } F 1, \\
& a_{4}=0.54 \text { for } F 2, \\
& a_{4}=-0.54 \text { for } F 3, \\
& a_{4}=-1.30 \text { for } F 4 .
\end{aligned}
$$

Thus $F 2$ and $F 3$ are the optimal feeding vectors.

(b) $n \neq 2^{m}$

In case $n \neq 2^{m}$ the similar theorem as in case $n=2^{m}$ has not yet been obtained. But we can find the eigenvectors. The number of vectors in $C$ is finite for any fixed $n$, so that the optimal feeding vectors can be determined if all vectors are surveyed.

(c) A cubic model

A cubic model of a stratified feeding mixer and a probabilistic branching model mixer may be considered.

The characteristic equations for the transition probability matrix of this model can be represented by the same equation as $s_{n}(y)$ in Appendix A, whose argument $y$ is a matrix. Our theory can be applied also to this model and it shows the following pattern to be optimal for $n=16$.

$$
\begin{aligned}
& 0110 \\
& 1001 \\
& 1001 \\
& 0110
\end{aligned}
$$

The details of this model will be reported elsewhere.

(d) The case that interference among particles exists.

Some kind of interference may be modeled by taking $p$ greater that $1 / 2$. In section 3, we showed that eigenvectors do not depend on the values of $p$ and $q$. Then, our result for optimality still follows. However, real mixing processes show more complex interference, and so we need further steps in this research.

\section{Acknowledgment}

The authors wish to thank Professor Y. Akao and Mr. H. Shindo for their helpful suggestions and critical reading of the paper. 


\section{References}

[1] Akao, Y., Yoshizawa, H., Uehara, S. and Noda, T.: Studies on the Mixing Processes Based on an Elementary Mode1. Proceedings of the Tohoku Conference of the Society of Chemical Engineers, Japan, 1970.

[2] Akao, Y., Shindo, H. and Angel, H.: Synthesis of a Mixing System and Its Optimal Feeding Strata. Journal of the Soeciety of Powder Technology, Japan, Vol.19, No.3 (1982), 639-645.

[3] Angel, H., Iwanami, K., Suzuki, R., Shindo, H. and Akao, Y.: Synthesis of a Mixing System and Its Optimal Feeding Strata. Proceeding of the 11th Conference of the Society of Chemical Engineers, Japan, 1977.

[4] Fan, L. T., Lai, F. S., Akao, Y., Shinoda, K. and Yoshizawa, H.: Numerical and Experimental Simulation Studies on the Mixing of Particulate Solids and the Synthesis of a Mixing System. Computers and Chemical Engineering, Vo1.2, (1978), 19-32.

[5] Snyder, M. A.: Chebyshev Methods in Numerical Approximation. Prentice , Ha11, N, J., 1966.

[6] Van der Waerden, B. L.: Modern Algebra. Springer-Verlarg, Berlin, 1937.

Keisuke UCHIMURA: Department of Computer Science, Faculty of Engineering, Yamanashi University, Takeda 4-3-11, Kofu, Yamanashi, 400, Japan. 
Appendix A

Eigenvalues and eigenvectors of the probability matrix $P$.

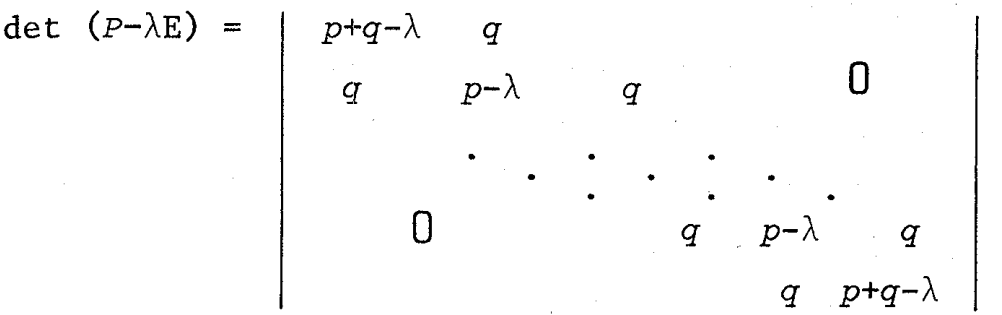

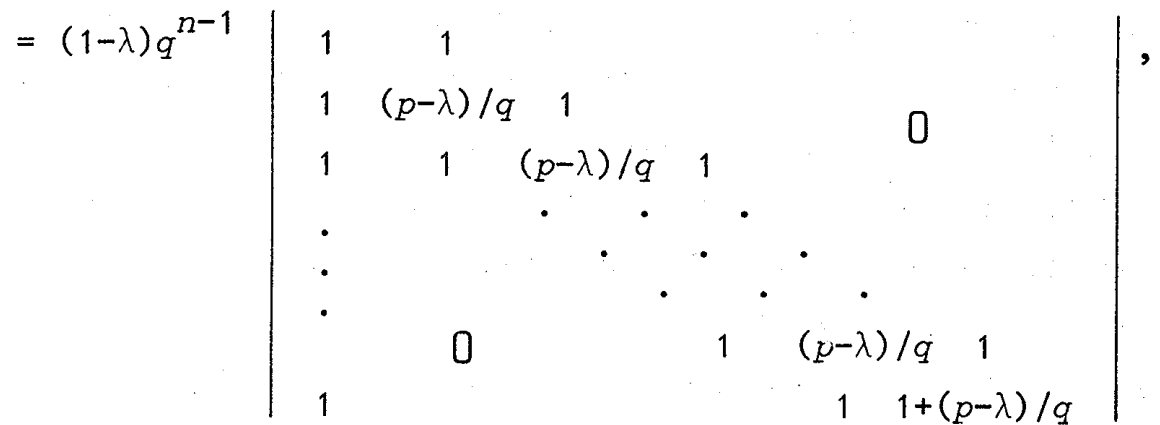

where $E$ denotes an $n \times n$ unit matrix.

Let $y=(p-\lambda) / q$.

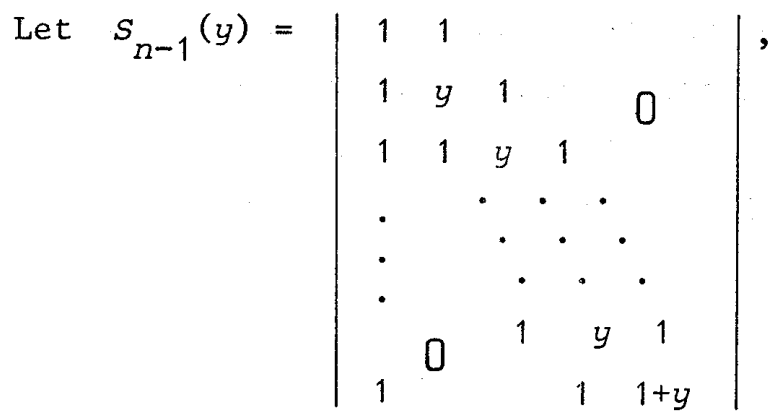

where the right side is the determinant of an $n \times n$ matrix. It can be easily seen that

$s_{2}(y)=y^{2}-1, \quad s_{3}(y)=y^{3}-2 y$, and $s_{n}(y)-y S_{n-1}(y)+s_{n-2}(y)=0$, for any $n \geqq 4$. Note that $S_{n}(y)$ is a polynomial of degree $n$ being odd or even as $n$ is odd or even. It is clear that if $n$ is odd, then $S_{n}(y)$ is divisible by $y$ and $S_{n}(y) / y$ is even. It follows that if $z$ is a zero of $S_{n}(y)$, then $-z$ is also a zero of $S_{n}(y)$. It is known that $S_{n}(y)$ is a version of the Chebyshev polynomial of the second kind (See [4]). Hence

$$
s_{n-1}(2 \cos \theta)=(\sin n \theta) / \sin \theta \text {. }
$$

Clearly each zero $y_{j}$ of this polynomial is determined by the element $\theta$ such that $\sin n \theta=0$ and $\sin \theta \neq 0$. 
Thus $y_{j}=2 \cos (j \pi / n)$. By the remark mentioned above, $-y_{j}(1 \leqq j \leqq n-1)$ is also a zero of $S_{n-1}(y)$. Then we order $\lambda_{j}$ 's as follows:

$$
\lambda_{j}=p+y_{j} q, \quad 1 \leqq j \leqq n-1 .
$$

Since $(1-\lambda)$ divides $\operatorname{det}(P-\lambda E)$, it follows that $\lambda_{0}=1$. It is clear that

$$
\lambda_{0}>\lambda_{1}>\lambda_{2}>\ldots>\lambda_{n-1} .
$$

Further if $p \geqq 2 q$, then $\lambda_{n-1}>0$.

Next we show eigenvectors of $P$. Clearly an eigenvector corresponding to $\lambda_{0}$ is the vector $(1, \ldots, 1)$. For each eigenvalue $\lambda_{j}(1 \leqq j \leqq n-1)$, we shall find an eigenvector $\left(u_{j, 0}, \ldots, u_{j, n-1}\right)$. Clearly it satisfies the following condition:

$$
\left[\begin{array}{ccccc}
{ }^{1-y_{j}} & 1 & & \\
1 & -y_{j} & 1 & & 0 \\
& \cdot & \cdot & \cdot & \\
& \cdot & \cdot & \cdot & \\
0 & & 1 & -y_{j} & 1 \\
\vdots \\
\cdot \\
u_{j, n-2} \\
u_{j, n-1}
\end{array}\right]\left[\begin{array}{c}
u_{j, 0} \\
u_{j, 1} \\
\cdot \\
\cdot \\
0 \\
0
\end{array}\right]
$$

Let $\zeta=\exp (2 \pi i / 4 n)$. Clearly $\zeta^{4 n}=1$ and $\zeta=\cos (2 \pi / 4 n)+i \sin (2 \pi / 4 n)$. Hence $y_{i}=2 \cos (j \pi / n)=\zeta^{2 j}+\zeta^{-2 j}$. Let $u_{j}={ }^{t}\left(\zeta^{j}+\zeta^{-j}, \ldots, \zeta^{j(2 k+1)}+\zeta^{-j(2 k+1)}, \ldots, \zeta^{j(2 n-1)}+\zeta^{-j(2 n-1)}\right) / 2$. Then the vector $u_{j}$ is an eigenvector to $\lambda_{j}$. Indeed.

$$
\begin{aligned}
& \begin{aligned}
&\left(1-y_{j}\right) x_{0}+x_{1}=\left(1-\left(\zeta^{2 j}+\zeta^{-2 j}\right)\right)\left(\zeta^{j}+\zeta^{-j}\right)+\zeta^{3 j}+\zeta^{-3 j}=0 . \\
& x_{k-1}-y_{j} x_{k}+x_{k+1}= \zeta^{j(2 k-1)}+\zeta^{-j(2 k-1)}-\left(\zeta^{2 j}+\zeta^{-2 j}\right)\left(\zeta^{j(2 k-1)}+\zeta^{-j(2 k+1)}\right) \\
&+\zeta^{j(2 k+3)}+\zeta^{-j(2 k+3)}=0, \\
& x_{n-2}+\left(1-y_{j}\right) x_{n-1}=0, \text { where } x_{k}=\zeta^{j(2 k+1)}+\zeta^{-j(2 k+1)}, 0 \leqq k \leqq n-1 . \\
& \text { Note that }\left(u_{j}, u_{k}\right)=0 \quad \text { if } j \neq k \\
&=n / 2 \text { if } j=k
\end{aligned}
\end{aligned}
$$




\section{有限マルコフ連鎖における最適問題と その固体粒子混合への応用}

$\begin{array}{ccccc}\text { 山梨大学 内 村 桂 } & \text { 輔 } \\ & \text { 吉 沢 } & \text { 正 } \\ & \text { 志 村 健 一 }\end{array}$

ある種のマルコフ連鎖について，定常分布への収束の速度が早いという意味で最適な初期確率 分布を求める問題を解く。乙れは赤尾等の提案した固体粒子混合過程のモデルの研究から生じた。

赤尾等は混合過程を移動と拡散とに分離し, 拡散に対しては等確率分岐モデルを提案し, 移動 に対しては固体粒子の層形成の問題とした。そして最適に形成された粒子層を拡散のみからなる 混合過程に供給するという合成混合システムを考え，本文図 1 のような上部に粒子層の供給口を 持ち，粒子が中間の六角形障害物の間を等確率に分岐しながら落下するモデル混合機によって害 験を行った。

その等確率分岐モデルは供給口の数 $\mathrm{n}$ と同数の状態と, 対称三重対角推移確率行列 $\mathrm{P}$ を持つマ ルコフ連鎖とみなされる。粒子は 2 種で同形同質とし，半数ずつの供給口がそれぞれの粒子に割 り当てられ同量が混合されるとする。2 種の一方に着目してその粒子の濃度で初期の層供給のパ ターンを表現すれば，それは 0 と 1 の列となる。そのパターンを初期供給べクトルと呼び, $\mathrm{p}(0)$ と書く。

$\mathrm{N}$ 段後の濃度べクトル $\mathrm{p}(\mathrm{N})$ は， $\mathrm{p}(0) \mathrm{P}^{\mathrm{N}}$ で与えられる。 $\mathrm{p}(\infty)$ は定常状態として確率的な完 全混合状態を表わし，(1/2，，1／2）となる。 $\mathrm{p}(\mathrm{N})$ は状態の確率分布に比例するとして 扱える。赤尾等は，例えば $\mathrm{n}=16$ の場合， $\mathrm{p}(0)$ を $(1,0,0,1,1,0,0,1,1,0,0,1,1,0,0,1)$ と， 1001 または 0110 のくりかえしとすると，他の場合にくらべて圧倒的に早く完全混合状態に近 ずくことを示した。本論文はその結果に対する数学的基礎を与える。

本論では, $\mathrm{n}$ 次確率行列 $\mathrm{P}$ の固有值 $\lambda_{0}>\lambda_{1}>\cdots>\lambda_{n-1}>0$ と固有ベクトル $\mathrm{u}_{0}, \mathrm{u}_{1} \cdots$, $\mathrm{u}_{n-1}$ を求め, $\mathrm{p}(\mathrm{N})$ と $\mathrm{p}(\infty)$ の差のノルムを

$$
\|\mathrm{p}(\mathrm{N})-\mathrm{p}(\infty)\|=\left(\sum_{j=1}^{n-1} \lambda_{j}^{2 \mathrm{~N}} \mathrm{a}_{j}^{2}\right)^{1 / e}, \quad \mathrm{a}_{j}=\mathrm{p}(0)^{t} \mathrm{u}_{j},
$$

と表わす。乙の量は $\mathrm{p}(0)$ の $\mathrm{p}(\infty)$ への収束の速度を与え，条件 $\mathrm{a}_{1}=\mathrm{a}_{2}=\cdots=\mathrm{a}_{k-1} \equiv 0$ ， $\mathrm{a}_{k} \neq 0$ を満たす $k$ に対する項 $\lambda_{k}^{2 \mathrm{~N}} \mathrm{a}_{k}^{2}$ によって支配される。そてで, 問題は上記の条件を満足す る $k$ を最大にする供給べクトル $\mathrm{p}(0)$ を求めるてとに帰着される。乙の問題を定式化して状態数 が 2 のべき乗の場合，1001 または 0110 のくりかえしである $\mathrm{p}(0)$ がその解であることを代 数学の円分体の性質を用いて証明する。

最適層形成の問題は製鉄所の高炉でのコークスと鉱石の混合やエンジンでのガソリンと空気の 混合など $\mathrm{R}$ 的な問題でも重要である。最適な初期確率分布が求まれば，最適な層形成が行え， 混合時間が著しく短縮されるという実用的効果がある。 